\title{
Social Context in Mangalua's Novel by Idris Pasaribu: A Literature Sociology Study
}

\author{
Meriah Kita Deliani ${ }^{1}$, Rosliani ${ }^{2}$ \\ ${ }^{1}$ Universitas Prima Indonesia, Indonesia \\ ${ }^{2}$ Pusat Bahasa Sumatera Utara, Indonesia \\ merkit7@gmail.com,mailto:rosliani.12@gmail.com
}

\begin{abstract}
This paper focuses on the world view of the author in the Mangalua's novel by Idris Pasaribu and the author's world view of social reality as depicted in the Mangalua's novel by Idris Pasaribu. This study used a qualitative descriptive method with a sociological literature approach. The data collection technique was carried out by document analysis, while the data analysis used descriptive qualitative methods. The results showed that this novel contains the social context in the novel which is depicted through the main character, social structure, marriage customs, and religion. The results of the analysis of social context with the approach of genetic structuralism in the novel, found that the author's world view is influenced by background, experience and insight, as well as social groups.
\end{abstract}

Keywords social context; genetic structuralism; sociology of literature

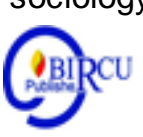

\section{Introduction}

One of the theories of Literary Sociology is Genetic Structuralism proposed by Lucien Goldman. In 1961, he founded his own institute for the study of literature and investigated the relationship between literature and sociology at the University of Libre Bruxelles. Goldman found that the sociology of genetic structuralism literature is a literary criticism that talks about an author who is influenced by social class, societal ideology, economic situation, and social conditions (Sikana, 2009: 267).

Goldman argues that a literary work is a reflection of society. A literary work is able to tell about a time. Literature has a close relationship with the context of the situation and the age with the system of thought and outlook on life of society, even has links to government and political systems. In this theory, events that occur in society are associated with social, cultural, economic, political phenomena and various dimensions of life. The author also has an important role in society. Theoretical research was carried out by Goldman using the concept of a structure that connects the elements of content and the form of literary works, as well as paying attention to the formalism of a literary text (Sikana, 2009: 270-271).

Literary work is the result of a writer's creativity that comes from life and is combined with the author's imagination. A novel is a literary work created from the author's imagination (Putriyanti, 2019). This happens because the author cannot be separated from a certain social context in society. Literature is part of the humanities sciences, such as language, history, art, aesthetics, and philosophy. All of these humanities are the essence of culture. Literary research is useful for understanding the human and cultural aspects contained in literary works (Pradopo, et al, 2003: 23). The themes in literary works from the past to the present are raised from social problems that occur in general in the midst of society. 
One of the most dominant literary works today is novel. The novel reveals a tense concentration of life at a time and a firm concentration of life (Semi, 1988: 32). The Mangalua's novel by Idris Pasaribu is a literary work that discusses social, cultural and political phenomena that occurred in the Bataknese community in ancient times. The author raises a historical theme that tells the Toba Bataknese community in carrying out the Mangalua's traditional event (eloping). The term of Mangalua is seen as disgraceful or embarrassing which can lower the dignity of the family concerned in the past. The author's description of the Mangalua's program in the novel shows the existence of a literary relationship with society which makes Mangalua's novel as one of the objects of study of the theory of Genetic Structural Sociology of Literature.

Until now, the theory of sociology of literature is still popularly used. According to Sikana (2009: 270) there are several important matters that are still being analysed, such as the relationship between the author's ideology and the literary text that he produces, social issues and problems raised by the author as the theme of his work, social values, aspects of impression and influence of literary works. To readers are as well as the history of literary development. From this, it can be concluded that a literary work which is an image work has a relationship with a real social context in people's lives.

Authors have an important role in the development of literary works. He is able to write stories with storylines and characterize the characters in his works. Social problems in society are conveyed from the author's perspective and translated into literary works. Likewise, the Mangalua's novel by Idris Pasaribu tells the situation of the people of Huta Porlak and Huta Bariba which are located in the Batak Toba region. In the story, it is said that the two Huta (villages) were always at war. The status of king did not guarantee equal social class at that time because Huta Porlak always won in battle. The Huta Bariba people and the royal family became slaves. In the end, this social class changed 180 degrees only because of the son of Raja Huta Porlak, Jogal, Mangalua and the daughter of Raja Huta Bariba, Ramondang.

Social problems in the Mangalua's novel by Idris Pasaribu are not only about social class, marriage customs, and politics, religious issues are also raised in the novel. At that time, people still believed in the ancestral religion of the Bataknese or Parmalimnese. According to them, the good things and bad things that come are gifts from the ancestors of the Bataknese community. After peace was established between Huta Porlak and Huta Bariba, the Dutch colonialists came to control the territory of the Bataknese people, including Huta Bariba and Huta Porlak. The Bataknese people were forced to convert to Christianity, but Jogal did not accept this, resulting in other bloodshed.

Sociology of literature is a view which states that literature is a description of social phenomena. In literary works, this phenomenon is raised as discourse with a creative process (observation, analysis, interpretation, reflection, imagination, evaluation, and so on). Research conducted on social phenomena in literary works aims to obtain a complete and useful picture of the reciprocal relationship between writers, literature, and society (Jabrohim, 2001: 169). Literary work must have the same function as other cultural aspects, so the only way is to return literary work to the midst of society, understanding it as an inseparable part of communication systems as a whole. From this explanation, it can be concluded that the sociological analysis of literature aims to describe the functions and criteria of the elements that make up a literary work seen from the social symptoms of the society in which the literary work was born. Thus, the sociological analysis of literature cannot be separated from the structural study of literary works. 
Structural study of literary works is an intrinsic approach that is oriented towards literary works from within the text. However, the most important thing is to show how the relationship between these elements and the contribution made to the aesthetic goals and the overall meaning to be achieved (Nurgiyantoro, 2000: 4).

The development of sociology of literature by utilizing the theory of structuralism is considered to have regressed, stagnated, and even considered as involution. Sociology of literature sees the social values of a literary work which makes it an extrinsic element of literary work. Therefore, a structural study of literary works is needed as a support in analysing the sociology of literature, considering that there are several things that need to be considered, including the relationship between literary works, authors, and society. Thus, the study of the social context in the Mangalua's novel by Idris Pasaribu first describes the intrinsic elements of the novel and then analyses the social context using the sociological approach of the theory of genetic structuralism by Goldman.

\section{Research Methods}

The research method is a way to answer the problem formulation. Thus, the methods used in conducting research must use appropriate methods. The structural and social context study of the Mangalua's novel by Idris Pasaribu uses descriptive qualitative methods. Descriptive qualitative method is a method used to reveal a variety of qualitative information with careful descriptions and to describe carefully something in data collection including analysis and interpretation (Sutopo, 2002: 8). The research report contains data quotations to provide an overview of the presentation of the report. In line with the opinion of Moeleong (2007: 11) is that the data is from the skin method (Sutopo, 2002: 8). The research report contains data quotations to provide an overview of the presentation of the report. In line with the opinion of Moeleong (2007: 11), that the data from the descriptive qualitative method is in the form of words, sentences, discourses, and pictures, not in the form of numbers.

Data are all information or materials provided by nature that must be sought and collected by researchers to provide answers to the problems being studied (Subroto in Imron, 2003: 112). Reference books and documents collected to analyse the social context and facts of the Bataknese community. Then, the research continued to the study stage of the Mangalua's novel by Idris Pasaribu using the Sociology of Literature approach to Genetic Structuralism theory to get a picture of the social context in the novel. The data in research on the Mangalua's novel by Idris Pasaribu are words, phrases, sentences and paragraphs, as well as events in the Mangalua's novel by Idris Pasaribu. Meanwhile, the data sources in this study consisted of two parts, namely primary data sources and secondary data sources. The primary data source in this study is the Mangalua's novel by Idris Pasaribu and the secondary data source is complementary data in the form of theoretical books, articles from journal sites related to the object of research focused on Sri Wahyuni's blog in "Idris Pasaribu Biography".

The data collection technique is done by using the library and note taking technique. The library technique is a technique that uses written sources to obtain data. While the note-taking technique is data that is obtained in written form, it must be read, the things needed are then collected and then studied the written source which can be used as a theoretical basis and reference in relation to the object to be studied (Subroto, 1992: 420). The data collection steps in the Mangalua's novel by Idris Pasaribu are (1) reading carefully the Mangalua's novel by Idris Pasaribu; (2) recording sentences related to novel structures and genetic structuralism in the novel; (3) to analyse the social context in the 
Mangalua's novel by Idris Pasaribu. From this technique, research data is obtained in the form of quotations in the form of clauses or sentences from the Mangalua's novel by Idris Pasaribu.

Data analysis was carried out with the aim of describing the data obtained. According to Sugiyono (2016: 246), the steps related to descriptive analysis include: Data collection and categorization, data, in the form of language units that have been collected classified according to the formulation of the problem; Data analysis was carried out after the data was classified and carried out data analysis in accordance with the theory used, in this case the data analysis was adjusted using sociological theory; Presentation of data is an advanced stage of analysis, where the data is classified based on the formulation of the problem and then the description is described; Drawing conclusions is the final step is to make inferences resulting from the analysis process in the form of descriptions.

\section{Discussion}

\subsection{Intrinsic Elements of the Mangalua's Novel by Idris Pasaribu}

According to Nurgiyantoro (2005: 23), intrinsic elements or inner structures that build literary works include: stories, events, plots, characterizations, themes, settings, storytelling points of view, language or language style, and so on. Extrinsic elements build literary works from the outside, in other words, extrinsic elements are other disciplines associated with imagery works (literature), including the sociology of literature and literary receptions.

The theme is one of a number of other story building elements in a literary work. In existence, the theme itself is very dependent on various other elements. The theme of a story cannot be conveyed directly, but only implicitly through the story. Themes are the basic binding elements or elements of story development (Nurgiyantoro, 1998: 74-76). The theme adopted from the Mangalua's novel by Idris Pasaribu is that change can be done through war. This can be seen from the quote below.

"I am very sure that he will be willing to meet with me, Amangboru ... so that there will be no more conflict between the two forests. There have been many victims from the war ... if you count them, there have also been many wives who lost their husbands and children who lost their fathers in our forest. We have to stop this and we will still be ready, if someone attacks us. Let's build our forest with better wealth. "(pp. 7-8).

The author of the Mangalua's novel by Idris Pasaribu describes the expected change in the story by uniting the son of the king from the Porlak huta and the Putri from the huta Bariba.

The plot or often called the plot is a storyline that forms literary works so that the story feels dynamic and alive. The plot applied in literary works can be in the form of a forward plot / plot, a flashback, and a mixed plot. Basically, the importance of the plot can be useful for a character who acts as a player so that the story can be understood by the reader. The plot used in Idris Pasaribu's novel Mangalua is a mixed plot. The mixed flow in question is event after event which is depicted in a forward manner which is then interspersed with events that have happened before (flashback). The story begins with the main character, Jogal, who wants to marry Siboru Anting na Rumondang. This triggered problems for the two forests. The following is a quote that illustrates the explanation of the flow above. 
"The Jogal wants to marry the daughter of the King of Tumpak, so Haribuan from the Bariba forest. ... they all knew, that Huta Bariba was a mortal enemy for three generations. Will there be another war? ... "( $p .5)$

Then it was followed by a flashback story of the meeting between Jogal and Siboru Anting na Rumondang so that the two figures decided to carry out Mangalua. The Mangalua's custom is told sequentially starting from the Mangaririt stage, Mangaluahon Si Boru Anting, and so on. At the end of the novel, a new problem arises, namely the arrival of Si Bontar Mata who wants to take over the Batak Land through the missionary religion it teaches.

Setting can be interpreted as the place, time and social conditions that support the story to make it easier for readers to understand. The setting used by the author in his work is able to reveal social conditions, as well as convey the message of his description. In addition, a character in a literary work plays a role in accordance with the surrounding background. Settings can help the reader understand the specific atmosphere that occurs in the story. The setting can give an impact on the attitudes and feelings of the characters in a story. The setting in the Mangalua's novel by Idris Pasaribu includes, Huta Bariba and Huta Porlak. This can be seen in the quote below.

"The music in the middle of the night made Siboru Anting and Tiur seem like they were floating in the sky. If only such a thing existed every night at Huta Bariba, what a wonderful life it would be. Enjoy sleeping accompanied by music. It is also a sign that the lives of the youth in Huta Porlak are much more compact and they really appreciate art. "(p.88)

Language is the author's delivery medium which functions as a creator of the right atmosphere in literary works. In other words, where activities occur, there is a language activity involved (Jegede, 2020). Each author has their own storytelling style. This can be seen from each of his works, where the choice of words and use of language are in accordance with the characteristics of the author. Idris Pasaribu shows his storytelling style through the Mangalua's novel. The use of the Toba Bataknese language term makes the reader feel more about the real Bataknese culture. This can be seen from the quote below.

"Naung tulus do roha muna na marsaripe?" Uluan asked... Jogal and Anting simultaneously pressed their palms together and brought them to their respective chests and replied: "Olo amang, naung tulus do roha nami."Yes, Your Honor, we have agreed and are determined. "(p. 144).

The term story character in literary works refers to the actor of the story. Each character is described with their own character. Character characters depicted in literary works are called characterizations. Story characters are generally differentiated into the main character and additional / supporting characters of the storyline in literary works. Meanwhile, in terms of role, characters are divided into protagonists and antagonists.

The main character in the Mangalua's novel by Idris Pasaribu is Jogal or Mangaraja Haro Parmonangan. The main character is described as someone who is stubborn, but has a soft heart, likes to help and speaks polite words.

"There were various kinds in their minds, when they let the five young men go. Some say in his heart, Jogal is indeed a stubborn young man, but his heart is so soft and helpful and speaks very politely. "(P. 11)

Additional characters in the Mangalua's novel by Idris Pasaribu include, Siboru Earring na Rumondang plays the wife of Jogal or Mangaraja Haro Parmonangan; Tiur ni Ari as a friend and servant of Siboru Anting na Rumondang; Further additional figures 
related to the main character, namely Tuani, Martua, Binsar and Poltak as Jogal's friends as well as Jogal's bodyguards.

\subsection{The Social Context of Mangalua's Novel by Idris Pasaribu}

Many readers appreciate Mangalua's Novel by Idris Pasaribu. The cultural description of the Toba Bataknese tribe community is the reason most of the readers. Initially this story begins with the main character named Jogal, who is the son of King Parhujinjang from the Porlak Huta married to Siboru Anting na Rumondang who is the son of the king of Tumpak so Haribuan from the forest of Bariba, Huta Porlak's arch enemy.

Huta Porlak and Huta Bariba are two regions that have been fighting for generations. Raja Tumpak so Haribuan was the mortal enemy of Mangaraja Parhujinjang. In another case, Jogal, who is the son of Mangaraja Parhujinjang, made the act of 'eloping' to unite the two huta (village). The actions taken by the main character to unite Huta Porlak and Huta Bariba were successful.

Mangalua (eloping) is a Bataknese traditional that has been carried out from generation to generation. One of the reasons this tradition is carried out is because the couple who performs Mangalua do not have enough assets to be used as Sinamot / dowry or dowry. However, the main character wants to take another action, namely changing the situation or wanting peace.

After practicing the Mangalua's custom, the male family came to the Huta Bariba, where Si Boru Anting lived, to perform Manuruk-nuruk events. The goal is to apologize. Apologies from male families are to women's families for taking their children away and breaking customs.

After the Manuruk-nuruk, it is followed by the handing over of the tuhor (dowry) to the woman's family as a sign of having paid the customary fine. The family of the woman has the right to ask for a dowry and this must be granted by the family of the male party. This is the same as what Jogal had done to Si Boru Anting na Rumondang. Then, the family of Si Boru Anting asked for a large dowry, because they were sure that Huta Porlak was able to do it.

After paying a customary fine or handing over a tuhor, a blessing ceremony will be carried out, which is called the King of Pasu-Pasu. The ceremony is carried out by the king to the bride and groom. After the blessing ceremony by the king, then the man will be legally declared as the partner of the woman and all the wrongs that have been committed by men, namely taking the woman away, will be eliminated.

\section{a. Author's Worldview}

The world view is a major problem in genetic structuralism. Social class, survey structuralism, and trans individual subjects are directed at the totality of answers that are answered as a research.

When viewed from the socio-cultural background of the author, Idris Pasaribu, it can be seen that there is no specific relationship between the author and the literary work he produces. IP began writing while in junior high school to follow the instructions of the GSNI (Indonesian National Student Movement). He has also worked as a journalist in many mass media offices. This made IP has broad insights and a lot of experience so that IP began to write about cultural aspects, especially Bataknese culture.

The worldview of the author, Idris Pasaribu, in Mangalua's Novel describes a society that still maintains their ancestral teachings. This ancestral teaching has been 
carried out from generation to generation and still supports traditional values. This thinking is often termed conservatism.

Conservatism is a thought that supports traditional values. This term comes from the Latin word conservation, which means to preserve; health, rise, and practice ". The description of conservatism thinking becomes a conflict in the Mangalua's novel by Idris Pasaribu. This can be seen in the following quote.

"Nineteen years Mangarajara Haro Parmonangan was in exile, until he was fluent in the language of the exile. In that exile, he was constantly lectured by people who said he was from the Banua Niha Ktristo Protesta, about a human saviour. He persisted in the teachings of his ancestors, although almost every Sunday he heard in his prison people singing and praying ... "(p. 292).

Samuel Francis said that conservatism is an attitude of defending and strengthening certain people, as well as institutionalized expressions of their culture. Meanwhile, Roger Scruton calls it "social ecological preservation" and "postponement politics" whose purpose is to maintain, as long as possible, the existence as life and health of a social organism.

Idris Pasaribu was born on 5 October 1952 in Marindal Delitua. He is the first child of 9 children. Idris Pasaribu is the son of a retired army class 45, Mr. Cornill Pasaribu and Mrs. Marianna Purba. His father was a member of the PNI (Indonesian National Party) laskar indirectly affecting his life. During Idris Pasaribu's life, he was known as a diligent and smart child. It was known that he was able to write and read before he started school. before entering school he was able to write fine rough and also Latin.

Idris Pasaribu's works focus on social phenomena wrapped in his imagination. "A Holy $\mathrm{Sin}^{\prime}$ is a very memorable thing because besides personal experience, his essay also gets responses from writers. One year later, he went to Jakarta to visit the writer H.B. Jassin. H.B. Jassin was surprised that Idris was 18 years old, even though he thought Idris was old because the languages he used were considered too mature. Then Gunawan Muhammad came and asked him what his response was to their criticism, but he answered casually and smiled. They assumed that he would give a response or rebuttal, but in fact he did not give a serious response because he thought it was just another person's opinion.

Idris Pasaribu also has a unique name for each of his writings, namely "Ris Pasha" (pen name). The name is always there in every writing. This name often appears in women's magazines such as Sarinah, Femina, Kartini and so on.

Now Idris Pasaribu is still active in LKN, but he also works at the Harian Analisa section of the Cultural Editor and is also the deputy chairman of the Central KSI (Indonesian Literary Community) in Jakarta. Now Idris Pasaribu no longer lives in Deli Tua but lives at the Housing Villa Palem Kencana Block XY, Jl. Pinang Mas 10 No. 11. Not only working as a Cultural Editor at the Harian Analisa, Idris Pasaribu continues his field of art and literature. So that he is the founder of Public Children's Theatre which was founded in 1997 which is located at Cultural Park. Public Children's Theatre was founded not only by Idris Pasaribu, but with his friends, namely: Hafiz Tahadi, Dra. Cut Mutia Mutriyola, Aisyah Basyar, Drs. Mangatas Pasaribu.

At Public Children's Theatre, they are more focused on theatre, they are very active and often staged documentary films. The members at Public Children's Theatre are the same as those in KSI (Indonesian Literature Community). They are not only writers, but they are able to carry out stories so that they become documentary films. There have been many works that have been produced.

His intense activity in the world of national literature increased because when he was Chairman of the Indonesian Literary Community (KSI) in Medan. Entering the age that 
most people use to relax, Idris Pasaribu is still struggling with his dreams. Apart from working on the film Amang Pasinuan, he is still preparing for novels. If you want to meet Idris Pasaribu, there will be no difficulty meeting him. He is easy to find at the North Sumatra Cultural Park (TBSU) just "Under the Tamarind Tree" every Saturday at 15.00 WIB. This is a place for Idris and his students to discuss and share their experiences.

\section{b. The Author's World View of Social Reality in Mangalua's Novel By Idris Pasaribu}

The social context in the novel is obtained by describing the author's world view of social reality. In this discussion, the context of the author's world view of the main character will be described, the context of the author's world view of social structures in society in the novel, the use of terms, politics, culture, and the context of the author's world view of religion.

The context of the author's world view of the main character can be seen in the way Idris Pasaribu describes the attitude of the main character in the story. Idris Pasaribu uses his distinctive storytelling style with the use of Toba Bataknese language terms. Jogal is described as a person who loves and nurtures his culture. Jogal has a fixed stance, stubborn, but still with polite character and speech towards older people.

This can be seen from the quote below.

"He doesn't want to be independent. What he wants is Sibontar Mata, not to disturb their forest and its people. They didn't want to be chased by Sibontar Mata like 21 years ago, until Sisingamangaraja was shot. ... Any natives who become traitors, must be beheaded. ... Is the Eyebrow person human? Taking people's property, citing blasting as high as possible and extorting the native power?" (p. 267).

The struggle and effort to defend the ancestral religion is also a picture of the main character, Jogal. The principles and thoughts of the main character belong to a conservative ideology. The main character is depicted as holding tight to the culture of the ancestors, maintaining, maintaining, and practicing their existence.

The context of the author's world view regarding the social structure of the Bataknese community consists of kinship structures and marriage customs. The kinship structure starts from the Bataknese myth, the meaning and function of the clan, the structure of the clan, the structure of marriage and exchange, and the structure of kinship terminology. (Simanjuntak, 2016: 74)

The search results on the Mangalua's novel by Idris Pasaribu found that the author did not really emphasize the structure of the clan. Historically, the Bataknese recognized the existence of a myth about the origin of the Bataknese people having descended from two moiety of two Bataknese children of the king who were named Tatea Bulan Teaher and The king of Isumbaon. From these two genera emerged clans in the Bataknese land until now.

The Batak people represent a traditional food cooking tool with three stones as a symbol of their social structure. The term dalih na tolu, this social structure there are three important groups in Bataknese society, namely hula-hula, boru and dongan sabutuha (dongan tubu). The Dalihan $\mathrm{Na}$ Tolu structure contains the Hula-hula which is a group that is highly respected and of high position. Hula-hula are often called the visible God (debata na tarida). The position of the hula-hula is very high in the spiritual and physical perspective of the Batak people. Boru or Parboruon is a group of wife recipients. While the dongan sabutuha is a clan group that has one ancestor. Usually defined as a friend to one stomach, from one mother. (Simanjuntak, 2016: 98-100). 
The social context of the author's world view of culture (marriage customs). Bataknese marriages are marriages with people outside their own clan. Marriage with the same clan is strictly prohibited, if there is a one tribe in family (close family) marriage, as a consequence, they are expelled from the village. However, if the marriage occurs in the same family but it is far from family ties, then a way is to look for with Manompas Bombong. Manompas Bombong is a ceremony performed so that new clans emerge. (Simanjuntak, 2016: 103).

There are several types of marriage customs in Bataknese culture, including mangambing, mahuempe, maiturun, sonduk hela, pagodanghon. Mangalua is a custom of marriage in Bataknese culture. Mangalua is part of the mangambing or mahuempe. Mahuempe and mangambing are almost the same, namely one of the parties who use coercion or violence. The difference is, Mangalua is not done by force and is often referred to as "eloping". In ancient times, if a girl was taken away from the village, it meant that the man was labeled "pajolo gogo, papudi uhum" which meant putting strength and straddling the law. In other words, the man was embarrassing the village on purpose. This can trigger a war between forests. (Simanjuntak, 2016: 104-105). The custom that must be paid by the man also exceeds that of the Sinamot in general, depending on the request of the woman's family. (Simanjuntak, 2016: 141).

"Their presence is to ask about the tuhor / dowry that they have to submit later and everything. The dowry requested is ringgit sitio sound or gold ringgit seratur and seven buffaloes as a customary fine. While the buffalo to be slaughtered in the feast were provided by them from Raja Huta Porlak. "(P. 124).

This is also in line with the story excerpt in the Mangalua's novel by Idris Pasaribu. The novel's story still maintains the true Bataknese culture. The Mangalua customs depicted in the novel are in accordance with the customs in real life in the past. There was the action of the woman's Mangaluahon, the occurrence of clashes and bloodshed between the village youths, then the payment of a large customary or sinamot fine at the request of the woman.

The social context of the author's world view of religion. In the novel Mangalua by Idris Pasaribu, there is a reference to Sisingamangaraja being shot dead by the Bontar Mata group. This is the reason for Jogal or Mangaraja Haro Parmonangan to refuse Si Bontar Mata to negotiate on the spread of the gospel (missionary religion).

Jogal always maintains the culture of his ancestors, so they are willing to fight to get rid of Si Bontar Mata's gang. This is in line with the determination of the King of Batak, Sisingamangaraja XII, who fought against the Dutch so as not to spread Christianity. At first the Dutch made a peaceful approach, but Sisingamangaraja XII rejected them, so the Dutch invaded Toba to subdue it. The war was known as the 30 years Batak War (18771907). (Sihombing in Simanjuntak, 2016: 41).

In the beginning, the Bataknese people did not follow any religion from outside. They believed in a God called Mula na Jadi Nabolon, Ompu Raja at first, Ompu Raja Mulajadi. They also believe in three Gods, each of which has its own power in the universe and in the world. Debata Batara Teacher who mastered banua ginjang (upper world). Ompu Silaon Nabolon or Debata Sori who rules banua tonga (middle world). Mr. Pane na Bolon who becomes a place of eternal trouble. The highest is Debata Mulajadi na Bolon and the third is an incarnation. (Simanjuntak, 1966: 75-76). Belief in Debata Mulajadi na Bolon is also seen in Mangalua's novel by Idris Pasaribu.

"After all the equipment for making solu was placed on the ulos, machete, ax, and tuhil or chisel, Jogal started kneeling facing the tree. His mouth was 
moving after he brought his palms together. He faced upwards, begging Ompu Mulajadi na Bolon. Asking permission so that a tree that he creates, they cut down to make a solution."

"After all the equipment for making solu was placed on the ulos, machete, hatchet, and tuhil or chisel, Jogal started kneeling facing the tree. His mouth was moving after he brought his palms together. He faced upwards, begging Ompu Mulajadi na Bolon. Asking permission so that a tree that he creates, they cut down to make a solution."

"Mangaraja Parhujinjang also called Namartua Ihutan. Namartua Ihutan is the spiritual leader of their religion in the Porlak forest. "

This shows that parmalimnese or ancestral religions also teach the same thing in novels and real life.

\section{Conclusions}

Research on the social context of the Mangalua's novel by Idris Pasaribu was carried out using the sociology theory of genetic structuralism literature. The social context of Mangalua's novel by Idris Pasaribu is analysed by collecting data related to social issues contained in the Mangalua's novel by Idris Pasaribu. The observations are based on Goldman's Genetic Structuralism, namely that the author's world view is influenced by the socio-cultural background and groups and social activities of the author, as well as the author's experiences and insights; The social context described by the author of the Mangalua's novel by Idris Pasaribu regarding social reality can be seen from the following, including the social context depicted through the main character, the social context depicted through social structures, the social context depicted through culture (marriage customs), and the social context described through the development of religion.

\section{References}

Faruk. 2012. Metode Penelitian Sastra: Sebuah Penjelajahan Awal. Yogyakarta: Pustaka Pelajar.

Jabrohim. 2001. Metodologi Penelitian Sastra. Yogyakarta: PT Hanindita Graha Widya Jegede, O.O. (2020). Linguistic Features of English for Science and Technology. Britain International of Linguistics, Arts andEducation(BIoLAE) Journal Vol. 2 (2): 537551.

Moleong. 2005. Lexy J. Moleong. 2005. Metodologi Penelitian Kualitatif. Bandung: PT Remaja

Nasution, R. Mulia. 2020 Analisis Struktural dan Sosiologis Novel Mangalua: Perang Antarkampung, Kawin Lari, Ironi Adat Batak Toba. Jurnal Medan Makna: Vol 18, No 12020$)$ (20) https:/ojs.badanbahasa. kemdikbud.go.id/jurnal/index.php/medanmakna. Diakses 12 Januari 2021

Nurgiyantoro 2005. Sastra Anak, Pengantar Pemahaman Dunia Anak. Yogyakarta: Gadjah Mada University Press.

Nurgiyantoro. 2000. Statistik Terapan untuk Penelitian Ilmu-ilmu Sosial.Yogyakarta: Gama University Press.

Pasaribu, Idris. 2015. Mangalua. Jakarta: Yayasan Pustaka Obor.

Pradopo, dkk. 2003. Metodologi Penelitian Sastra. Yogyakarta: PT Hanindita Graha Widya 
Putriyanti, O.A., Winarni, R., and Rohmadi, M. (2019). Religious Education Values in Gita Savitri Devi's Rentang Kisah and Andori Andriani's Doriyaki Novels. Budapest International Research and Critics in Linguistics and Education (BirLE) Journal Vol 2 (4): $560-565$.

Ratna, K Nyoman. 2002. Paradigma Sosiologi Sastra. Yogyakarta: Pustaka Pelajar.

Ratna, K Nyoman. 2004. Teori, Metode, dan Teknik Penelitian Sastra. Yogyakarta: Pustaka Pelajar.

Ratna, K Nyoman. 2016. Teori, Metode, dan Teknik Penelitian Sastra. Yogyakarta: Pustaka Pelajar.

Rosliani. 2012. Hermeneutika Historis Novel Bokor Hutasuhut. Medan: Balai Bahasa Sumatera Utara

Semi, Atar. 1988. Kritik Sastra. Bandung: Angkasa Raya

Sikana, Mana. 2009. Teori Sastera Kontemporer. Singapura: Pustaka Karya.

Subroto. 1992. Penelitian Kualitatif. Jakarta: Raja Grafindo Persada.

Sugiono. 2016. Metode Penelitian Kuantitatif, Kualitatif, dan Kombinasi (Mixed Methods). Bandung: Alfabeta. 